\title{
WHY SHOULD SECURITY ASPECTS BE MORE SERIOUSLY CONSIDERED IN DEVELOPMENT OF SERBIAN TOURISM INDUSTRY?
}

\author{
Vesela Radović, Faculty of applied security, Educons University, Novi Sad \\ Ekaterina Arabska, University of Agribusiness and Rural Development - UARD, Plovdiv
}

\begin{abstract}
Tourism today is becoming a part of everyday life for millions of people all over the world. According to the Travel\&Tourism Competitiveness Report 2013, security is among the critical factors determining the competitiveness of a country's tourism industry. The most common reasons that are usually given are growing threats from terrorist acts, relatively high level of crime in the region and unknown diseases. The World Tourism Organization stated that one of the factors limiting the development of the industry is that issues related to security in tourism are not sufficiently regulated. The statistics show that the vast majority of organizations in tourism infrastructure are operating at a loss due to terrorism and natural disasters. This statement was particularly confirmed after a great decrease of tourist visits to Phuket and New Orleans after the horrible natural disasters (tsunami and hurricane Katrina, respectively). The question which arises in scientific and public community is: "How to provide an adequate level of security for tourists." Tourism is announced as one of the priorities in future development of the Republic of Serbia. The author used the methodology appropriate for social science. The study results have indicated an urgent need for acceptance of a holistic approach to the issue. Tourism industry has to recognize the importance of security in its daily activities and in these efforts needs to closely cooperate with security services on the local and national level.
\end{abstract}

Keywords: Risk, Security issues, Food safety, Tourism, Environmental security

\section{ZAŠTO BI BEZBEDNOSNE ASPEKTE TREBALO OZBILJNIJE RAZMATRATI PRI RAZVOJU TURIZMA U SRBIJI?}

Sažetak

Turizam postaje deo svakodnevice za milione ljudi širom sveta. Prema izveštaju Svetskog Ekonomskog Foruma Travel \& Tourism Competitiveness Report 2013, bezbednost spada u kritične faktore koji određuju konkurentnost turističke industrije jedne zemlje. Najčešći razlozi koji se obično daju jesu rastuća pretnja od terorističkih akata, relativno visoka stopa kriminala u regionu, kao i nepoznate bolesti. Svetska turistička organizacija saopštila je da je jedan od faktora koji limitiraju razvoj ove privredne grane taj što pitanja vezana za bezbednost u turizmu nisu adekvatno regulisana. Statistike pokazuju da velika većina organizacija uključenih u turističku infrastrukturu posluje sa gubicima usled terorizma i prirodnih katastrofa. Ova izjava naročito se potvrdila posle velikog pada turističkih poseta Puketu i Nju Orleansu nakon strašnih prirodnih katastrofa (pogođenih cunamijem i uraganom „Katrina”). Pitanje koje se javlja 
u naučnoj i stručnoj javnosti jeste: „Kako obezbediti adekvatan nivo bezbednosti za turiste?“. Turizam se najavljuje kao jedan od razvojnih prioriteta Republike Srbije u budućnosti. Autorke su koristile metodologiju primenjivu u društvenim naukama. Rezultati studija su ukazali na hitnu potrebu za pronalaženjem holističkog pristupa ovom problemu. Turistička industrija mora da prepozna značaj bezbednosti u svojim svakodnevnim aktivnostima i da u svom radu blisko sarađuje sa bezbednosnim službama na lokalnom i nacionalnom nivou.

Ključne reči: rizik, pitanja bezbednosti, bezbednost hrane, turizam, ekološka bezbednost

TIMS Acta (2016) 10, 71-80

\section{Introduction}

Stability of local economies is dependent on the extent to which state and local authorities are able to provide security (in its different aspects) for the territory, the residents and the guests, including tourists. In the contemporary world, travel and tourism sectors are often deemed as one of the most significant drivers of economic and social prosperity of a country or a region having relevant natural and human resources, legislation and institutional support). In the age of global tourism indispensable conditions for travel and tourism include safety and security and their importance has been growing in last two decades because of the decreased security, as a result of terrorist acts, local wars, natural disasters, epidemics and pandemics, etc. which necessitates studies in the relationship between security issues and tourism (Kôvári \& Zimányi, 2011). In that process, academic community and tourism workforce start to seek adequate holistic approaches that could provide mitigation of negative impacts in tourism industry jeopardizing destinations (Masfeld \& Pizam, 2005).

Talking about safety and security in tourism, it is important to clarify the notions and terms, used henceforth in the paper, because the difference between safety and security is not always evident based on the assumption that both describe conditions of protection (without risks) - protecting assets from hazards/threats creating safe/secure conditions. The safety condition is about being protected, while the security condition is about being free from danger (Fig. 1). Within the field of safety, hazards represent a risk to human health and lives, environment, production and material objects.
Protection embraces the values of an organization/ individual against planned, malicious and criminal incidents from a wide range of threats (Albrechtsen, 2003). Undoubtedly, every one study of those questions in the field of tourism would stress the importance of protection of tourists and protection of the area.

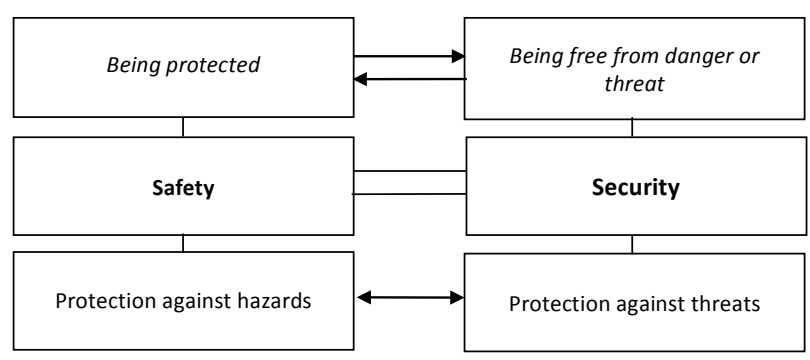

Figure 1. Main differences between security and safety (According to Albrechtsen, 2003)

The changing concept of safety and security in tourism from 1950 until now is scrutinized from the point of view of mass tourism evolving from being one of the problems in tourism - simplified approach in the perception of safety and security issues in tourism (19501970), via a period of enlargement of the security concept in tourism (1970-1990), to the complex perception of security and safety in tourism (Kôvári \& Zimányi, 2011). Nowadays security is an active element of tourism based on the obligatory condition to protect both tourists and industry and the challenges of globalization finding expressions in studies and discussions on risk management in tourism. The increasing frequencies and severity of security crises in last several decades, the feelings and perceptions of safety and security are changing, too which are the processes that affect tourists' decisions and travels. Taking into consideration the international environment of functioning of every 
single organization, including those in travel and tourism, the information both for tourists about destinations and tourist products and people offering tourist products is of great importance. It is dependent on the management in tourism on different levels and personnel qualifications.

Security and safety are now complex and multidimensional notions considering various components as political security, public safety, health and sanitation, personal data safety, legal protection of tourists, consumers protection, safety in communication, disaster protection, environmental security, getting authentic information, quality assurance of services etc. (Kôvári \& Zimányi, 2011).

Security threats' impacts on tourism impose policies and public means of enhancing security in travel and tourism industry through adequate security measures focused on prevention, preparedness and mitigation of human, reputational and economic consequences. Assuring security in tourism is the first step in the support of local socio-economic development and creation of employment opportunities. Twenty-one countries have joined and developed plans and other activities "to provide disaster managers, local and municipal and community planners, as well as other stakeholders in the tourism sector with a practical guidance on how to better prepare for disasters in coastal destinations" (Wilks \& Moore, 2004). Disaster prevention and management in Phuket province after horrible effects on tsunami is grounded in the National disaster management framework established by the Royal Thai government in the Disaster Prevention and Mitigation Act proclaimed on August $28^{\text {th }} 2007$ by His Royal Highness, the King of Thailand. This Act also established the National Disaster Prevention and Mitigation Committee (NDPMC) chaired by the Prime Minister (Kingdom of Thailand, 2007). Responding to numerous obvious challenges, the United Nations Environmental Programme - UNEP, in cooperation with the Caribbean Alliance for Sustainable Tourism (CAST), developed a useful practical handbook to support coastal tourism destinations to prepare and respond to natural disasters (UNEP \& CAST 2008).

Tourism can become one of the most important drivers of economic recovery and development (Jucan \& Jucan, 2013), but it could be highly sensitive to negative publicity, especially concerning increased levels of terrorism, crimes, violence, diseases or disasters. Tourism security and safety are transnational concerns and have become increasing challenges to countries all over the world in conditions of globalized business and creation of new social and cultural environment, challenges of insufficient resources (financial, material and human), climatic changes and environmental pollution, etc. International businesses functioning in unstable political situations and economic crisis suffer both the positives and negatives of globalization processes accenting sustainable development priorities, human capital and fairness. Positive trends and opportunities for tourism development worldwide are accompanied by a number of challenges and risks in contemporary conditions characterized by the ongoing processes of changes in national and international security systems' development out of the framework of traditional aspects.

Considering travel and tourism sector from the point of view of the opportunities for creating employment, generating revenues, forming an image of a country / an area, and fostering mutual understanding and respect, i.e. being a driver of economic and social prosperity, it should be underlined that it is a subject of security threats operating in an international environment.

\section{Tourism industry in global world: contemporary challenges and security linkages}

Tourism today is increasingly becoming a part of everyday life for millions of citizens all over the world. The World Tourism Organization stated that one of the factors limiting the development of the industry is that issues related to security in tourism are not adequately regulated. The statistics show that the vast majority of organizations in tourism infrastructure are operating at a loss due to terrorism threats, and natural disasters. Increasing the security level should envelop both physical and emotional safety, as security management in tourism is within the competencies of all - state and local authorities, tourism business, society and tourists. Adequate security measures focus on human safety, environmental safety and critical infrastructure protection relying on the procedures of prevention and 
monitoring in conditions of international collaboration for effective actions and/or reactions.

According to The Travel \& Tourism Competitiveness Report 2013 pointing Travel \& Tourism competitiveness enablers and change drivers security aspects are among the most important factors of travel and tourism competitiveness (Figure 2) because of the human, economic and reputational consequences and negative publicity.

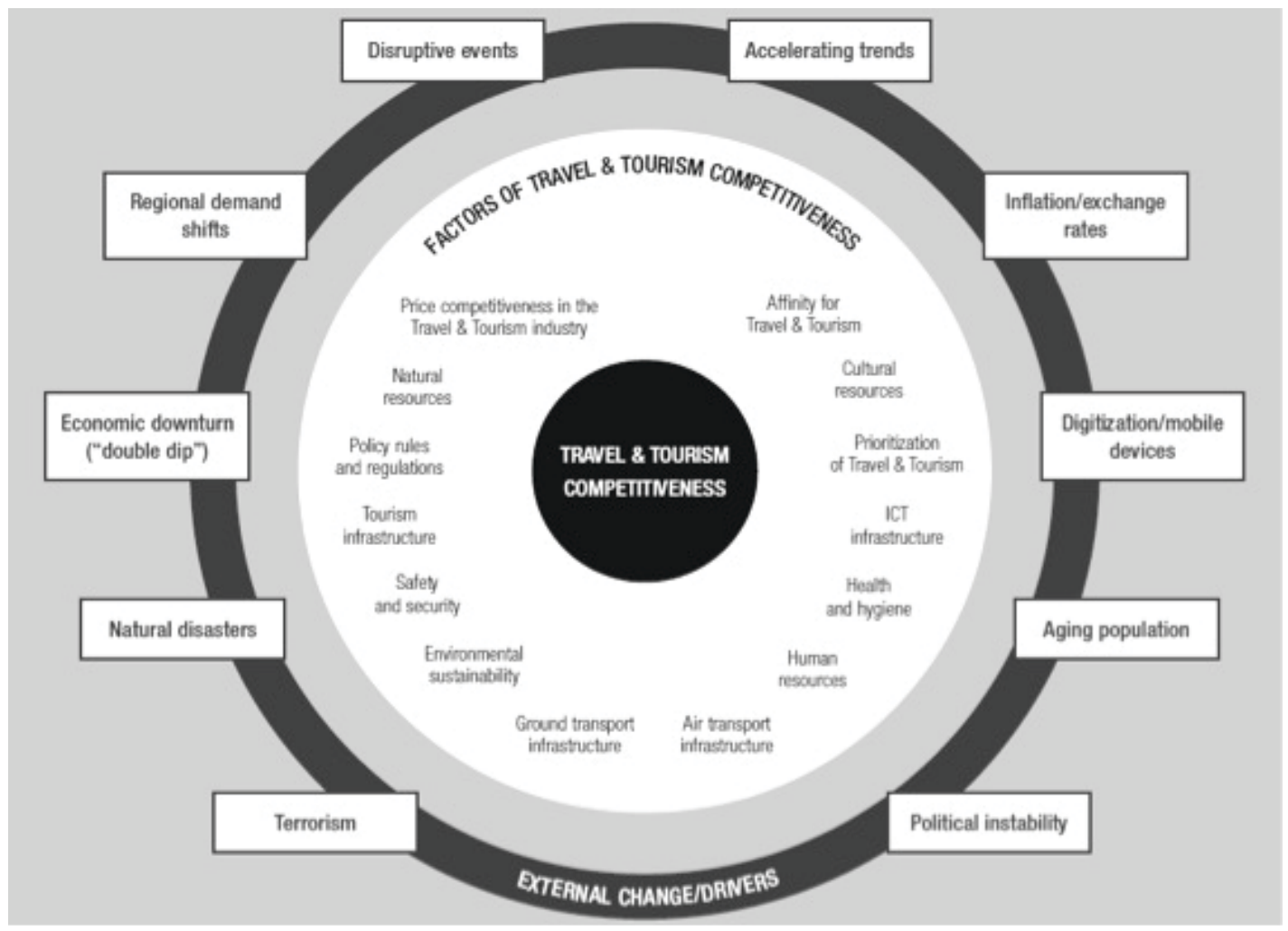

Figure 2. Travel \& Tourism competitiveness enablers and change drivers (Source: The Travel \& Tourism Competitiveness Report, 2013)

Yang \& Nair (2014) examine tourists' risk perception and find that uncertainty, worry, fear, and anxiety are closely related to risk perception, the notions used interchangeably in past studies, causing confusion in understanding tourists' experience with risk.

The subjective nature of safety is related to the notion of real and perceived safety in tourism - exaggerating some issues with little reason or underestimating serious risks (Maximiliano, 2014). For sustainable tourism programmes the real probability of danger and the effect on social imagery are important and risk communication should not be ignored (Maximiliano, 2014). Different kinds of risks generate different reactive adaptations and this should be taken into account when dealing with tourism safety in particular. Travelling hides a various number of risks and tourists undoubtedly make their choice not only on the basis of price or destination, but personal safety and security, as well.
In recent years, globalisation, terrorism, new technologies, political changes, economic integrations, concerns about environment, etc. have resulted in new trends in consumers' demand, also including tourism sector worldwide (Baldigara \& Mamula, 2012). The notion of sustainable tourism has grown up recently considering the potentials of the sector as an economic driver from the point of view of social, cultural and environmental dimensions. Discussing security as one of the keys to sustainable tourism, it is viewed as one of the most important factors that keep the visitors visiting the destination (Prashyanusorn, Kaviya, \& Yupapin, 2010). Threats that could impact travel and tourism industry are summarized on Table 1 embracing not only those traditionally addressed, such as terrorism, crime and military conflicts, but also environmental and health hazards. 
Table 1. A summary of threats that could impact travel and tourism industry

Crime-related incidents

Terrorism

Environmental

Climate change

Diseases / health hazards

Natural disasters

Unsafe travel conditions / local travel safety

Political situation / military conflicts

Nowadays, safety aspect becomes one of the prominent issues among tourists, especially in the urban tourism and the strategies for a "safe city program" could include: environmental design initiatives, target hardening, social activities / society education / public awareness (Anuar, Bookhari, \& Aziz, 2012)

Sustainability of tourism (environmental protection and promotion, natural and other resources preservation, cultural values and integrity of local communities) implies extensive cooperation between tourist business and authorities in order to cover a wide group of challenges and, at the same time, to remain competitive
(Angelkova et al., 2012). The competitive abilities of tourist destinations in an explicit way show the level of socio-economical development of tourist destination with a special regard to quality of life (Angelkova et al., 2012), i.e. "the ability of increasing tourist consumption in order to attract many more tourists, supplying them with memorable experiences which satisfy them and that is, at the same time, made in a profitable way by improving the wellbeing of people at the destinations, all the while preserving the natural heritage for future generations".

A study points out that there is a need for the formation of destination management and marketing organisations (DMMOs) in rural tourism destinations and identify their management and marketing roles (Adeyinka-Ojo, Khoo-Lattimore, \& Nair, 2014) summarized as follows: network management organisations, organiser, advocate, catalyst, tourism product developer, community brand builder, convener and facilitator, funding agent, information provider, partner and team builder. Roles of destination and marketing organizations could be divided into two groups (Table 2) underlying the framework of such organizations in which safety, security and crisis management are a key part.

Table 2. Roles of destination management and marketing organisations (DMMOs)

(Source: Adeyinka-Ojo, Khoo-Lattimore, \& Nair, 2014)

\begin{tabular}{ll}
\hline Destination Management Roles & Destination Marketing Roles \\
\hline $\begin{array}{l}\text { Human resource development } \\
\text { Finance and budgeting management }\end{array}$ & Destination marketing communication \\
& Destination positioning and branding \\
$\begin{array}{l}\text { Safety, security and crisis } \\
\begin{array}{l}\text { Politics (government, NGOs, community relations and } \\
\text { industrial relationship), policy and destination strategy }\end{array}\end{array}$ & $\begin{array}{l}\text { Management of tourism assets, attractions management } \\
\text { and sustainability }\end{array}$ \\
$\begin{array}{l}\text { Monitoring service quality, standards, and destination } \\
\text { performance management }\end{array}$ & $\begin{array}{l}\text { Selationship management (CRM) } \\
\text { relism }\end{array}$
\end{tabular}

In principle, the development of a sector is influenced by the political system of a country, its socio-economic environment and the policy framework and tourism policy has been discussed and defined by many authors as a statement of intent of a set course of action agreed upon by public body or agency, such as the government or a private organization (Kamble \& Bouchon, 2014).

Studies on disaster risk reduction and risk communication should pay attention to tourists, too as one of the vulnerable groups in tourism areas: tourists should be served better, including the aspect of safety in 
terms of the level of the risk knowledge and perception and critical awareness based on the participatory approach and local residents. (Susmayadi et al., 2014).

Carrying out in-depth analyses of of the T\&T competitiveness of economies around the world, the World Economic Forum (WEF) presents Travel \& Tourism Competitiveness Report proving "a platform for multi-stakeholder dialogue to ensure the development of strong and sustainable T\&T industries capable of contributing effectively to international economic development". The theme of 2013 report is "Reducing Barriers to Economic Growth and Job Creation" thus reflecting the importance of the sector for this purpose pointing the statistics that the sector already accounts for $9 \%$ of GDP, a total of US\$ 6 trillion, and it provides 120 million direct jobs and another 125 million indirect jobs in related industries.
The report underlines the remarkable resilience of the sector in the time of the "fragile recovery" of global economy. Furthermore, the report pays special attention to safety and security. The Travel and tourism competitiveness index (TTCl) aiming at measuring the factors and policies that make it attractive to develop the T\&T sector in different countries embraces categories summarized in the three subindexes comprising of 14 pillars of Travel \& Tourism competitiveness (Table 3) directly or not linked to security and safety in tourism, although the third one is specifically refered to safety and security described through: business costs of terrorism, reliability of police services, business costs of crime and violence, and road traffic accidents.

Gabor, Codrina, \& Oltean (2012) examine European countries' tourism competitiveness on the basis of the 14 pillars and statistics in the 2011 report and conclude

Table 3. Travel \& Tourism competitiveness index (TTCI) of WEF

\begin{tabular}{|c|c|c|}
\hline Subindexes of TTCI & Short description & Pillars \\
\hline $\begin{array}{l}\text { (1) T\&T regulatory framework } \\
\text { subindex }\end{array}$ & $\begin{array}{l}\text { captures those elements that are } \\
\text { policy related and generally under } \\
\text { the purview of the government }\end{array}$ & $\begin{array}{l}\text { 1. Policy rules and regulations } \\
\text { 2. Environmental sustainability } \\
\text { 3. Safety and security } \\
\text { 4. Health and hygiene } \\
\text { 5. Prioritization of Travel \& Tourism }\end{array}$ \\
\hline $\begin{array}{l}\text { (2) T\&T business environmentand } \\
\text { infrastructure subindex }\end{array}$ & $\begin{array}{l}\text { captures elements of the business } \\
\text { environment and the "hard" } \\
\text { infrastructure of each economy }\end{array}$ & $\begin{array}{l}\text { 6. Air transport infrastructure } \\
\text { 7. Ground transport infrastructure } \\
\text { 8. Tourism infrastructure } \\
\text { 9. ICT infrastructure } \\
\text { 10. Price competitiveness in the T\&T industry }\end{array}$ \\
\hline $\begin{array}{l}\text { (3) T\&T human, cultural, and } \\
\text { natural resources subindex }\end{array}$ & $\begin{array}{l}\text { captures the "softer" human, } \\
\text { cultural, and natural elements } \\
\text { of each country's resource } \\
\text { endowments, as well as climate } \\
\text { change }\end{array}$ & $\begin{array}{l}\text { 11. Human resources } \\
\text { 12. Affinity for Travel \& Tourism } \\
\text { 13. Natural resources } \\
\text { 14. Cultural resources }\end{array}$ \\
\hline
\end{tabular}

that the structure of the pillars that form the principal components of EU countries differ when compared with that of non-EU countries, as follows: for EU countries the determining pillar is human resources, followed by safety and security, compared with non-EU countries where the hierarchy is reversed, i.e. the first pillar is safety and security and then human resources.

\section{Serbian tourism industry and security aspects as an important factor for its development}

Transition process in Serbia, started in 2000 and still in progress, embraces different kinds of reforms influencing economic structure in favor of service sector, and particularly tourism as a great opportunity for the country's development because of the available natural conditions, cultural and historical heritage, social conditions, material base, favorable transportation and 
geographical position, but unfortunately the sector needs improvements and development on a sustainable basis in order to increase its competitiveness and positions on the international markets (Petrović-Ranđelović \& Miletić, 2012). Serbian tourism development is thoroughly presented in the Strategy of tourism development in the Republic of Serbia established by the Serbian Government (Serbian Government, 2006).

In Serbian report of the World Travel and Tourism Council (WTTC) it is stated that travel and tourism can also play an important role in the future development of Serbia. The industry makes a significant contribution to both GDP and employment. In 2011, Travel \& Tourism directly contributed $1.8 \%$ of Serbia's GDP and accounted for 32,100 jobs directly in Travel \& Tourism, representing $2.4 \%$ of total employment. Considering the wider impacts of the industry into account, Travel \& Tourism contributed $5.4 \%$ of GDP and 80,100 jobs in 2011 (6\% of total employment). Furthermore, the report envisages that over the next ten years and with the right policies in place, Travel \& Tourism in Serbia will achieve growth of $4.8 \%$ per annum, in terms of its contribution to GDP compared to $4.5 \%$ per annum growth in Travel \& Tourism in Eastern Europe and $4.3 \%$ in the world as a whole. The forecast is that the total contribution of Travel \& Tourism in Serbia to GDP will be to $6.8 \%$ of the economy in 2023 .

Among the challenges that should be carefully addressed in the near future are those of ensuring the long-term sustainable development of the industry "with maximum benefits for all stakeholders", including development of infrastructure and human capital. Cooperation between state and business, making and communicating Serbian tourism brand, integrating tourism into other industries and raising public awareness and support. Future sustainable tourism development in the country relies on "wise" investments and favourable state policies and institutional support. It is very important not only to identify priorities and plan actions, but also to "implement new policies lasting far beyond the party line or any political bias". According to the report of WTTC accountability and ownership stay at the heart of tourism development in Serbia and depend on the stringent performance management and quality controls. Cosidering the change of the poor perception of the country because of the war, now the opportunities are higher than ever before because of the globalization processes and the aspirations of the country development in the EU. The international direction of tourism development in Serbia is shown by the statistics in the report, as follows: 765,000 foreign tourists in 2011 contributed to more than a half of total internal tourism spending in 2011 (58.6\%) compared to 1.3 million domestic residents taking overnight trips and to the Eastern European average of $46.6 \%$. The expectations for next ten years for a solid growth just show the opportunities to start a new era of partnerships regarding the over-arching sustainable development priorities and travel and tourism place in policy development and future planning, including environmental management systems, community engagement and linkages to other sectors, especially agriculture and food.

Looking at the data in Travel \& Tourism Competitiveness Report 2013, Serbia is ranked 89th out of 140 , but going in depth of the index compounds safety and security is ranked better than most of the other pillars of $\mathrm{TTCl}$ (Figure 3). The report states that in the past years at the bottom of the European rankings are a number of Balkan countries (Serbia, Bosnia and Herzegovina, and Moldova) having less-advanced development and requiring significant investments in upgrading the infrastructure needed to support healthy and growing T\&T sectors.

The policy framework for Serbia in the Serbia report of the World Travel and Tourism Council is focused on sustainable development and long-term planning (Table 4). Development of sustainable tourism and security imposed effective procedures of planning, implementation, monitoring and control through a number of measures linked to environmental management system, health and hygiene, assuring food quality and safety and critical infrastructure protection. Competencies in the field of tourism security are not easily determined, but should not be limited to state and local authorities (Table 5). 
Radović, V., Arabska, E. - Consideration of security aspects in Serbian tourism industry

2016. Fakultet za sport i turizam, Novi Sad, TIMS Acta 10, 71-80

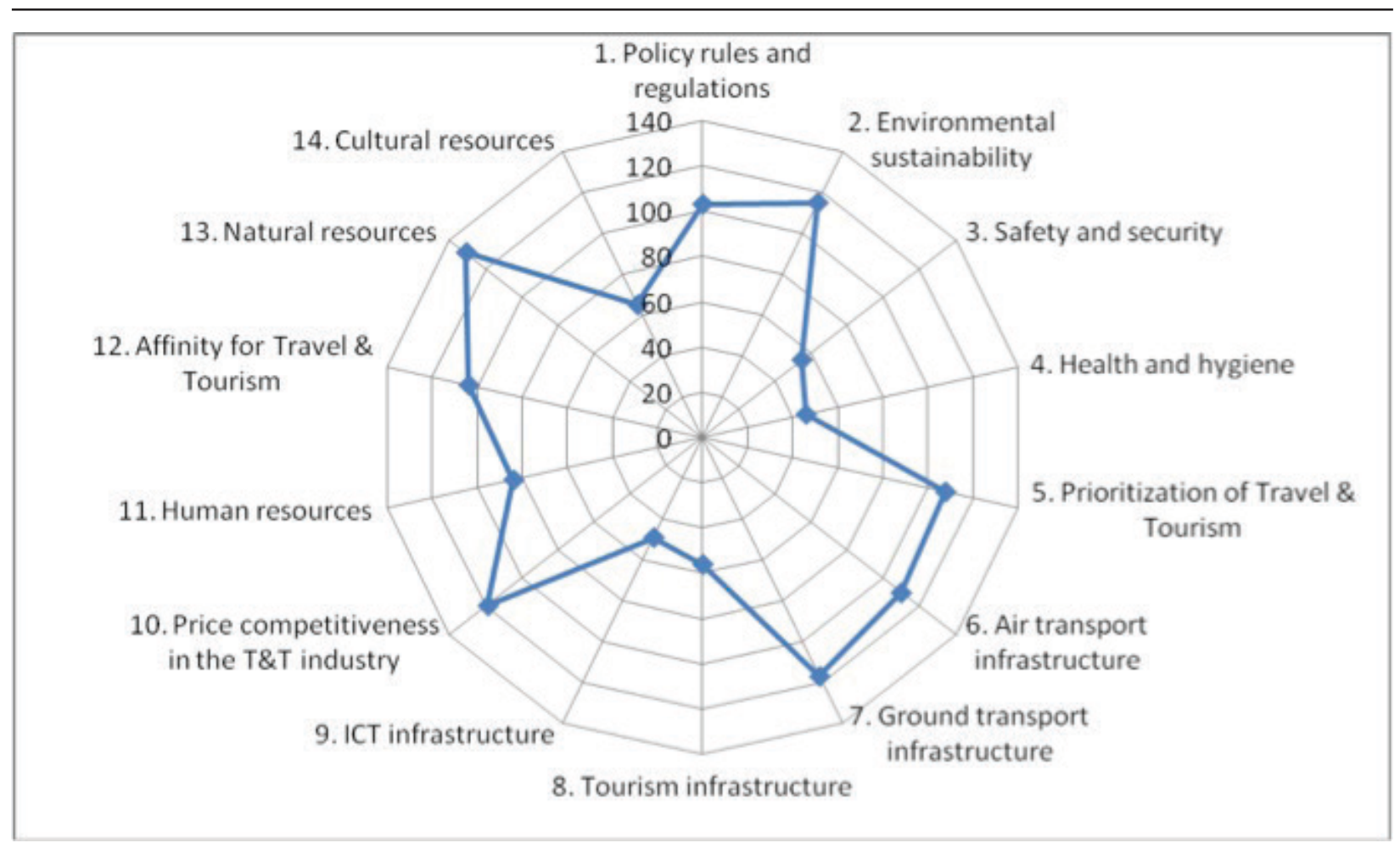

Figure 3. TTCl pillars for Serbia according to the Travel \& Tourism Competitiveness Report 2013 of the World Economic Forum

Table 4. The policy framework for Serbia (WTTC, Serbia report, 2014)

\section{Sustainable development}

Strategic value of travel and tourism

Long-term planning and research

Coordinated branding, promotion and marketing

Infrastructure development

Transparent business environment

Unique product differentiation and development

Investment in human resources and education

Table 5. Security competencies

State authority

Public-private partnerships

Citizens' participation

International collaboration

Tourists' feedback is very important, especially when considering perceptions and behaviours and the need of adequate and timely measures closely connected to knowledge and innovations' system, exchange of good practice, effective decision-making in disaster management and recover decisions, communication and capacity building.

All that implies the significance of two sides of the "coin" - image and perception management vs. risk and crisis management. Those are not identical, but they are not controversial either: image management strategies should include crisis management and, vice versa, the latter includes a number of communicational and other issues connected to the destinations' image and human perceptions, incl. those of tourists. The cooperation of public authorities and private organizations/people should be considered from the point of view of security related information and the type of source and media involvement. Risk management embracing preventive, reactive and recovery measures in crisis management, disaster reduction and mitigation plans should include also strategies to confront tourism crises and rules of collaboration starting from research on incidents types and frequency - motives, targets - severity - impacts (on the destination, on tourists' behavior, on tourism industry - reactions - recovery - prevention and reduction. The role of educational system should not be neglected in creating tourism safety perceptions and realities. 
In years when destinations become more competitive and concurrent with each other, a tourism development strategy is needed based on the participatory and integrated approaches in planning and management for sustainable development of the sector and the country as a whole, including marketing and promotion. The adopted Strategy of tourism development in the Republic of Serbia could be successfully implemented only with the organisation of adequate institutional infrastructure, which will included more aggressive enforcement of adequate security level in all four defined tourism regions. In that way, Serbia will be recognized as one of the safest destination on the European tourism map (Radović, 2010).

Bearing in mind the most important principles of sustainable tourism development it should stress the local community involvement, establishment of links between other local businesses and tourism, increasing capacity utilization, providing knowledge and information and achievement of international competitiveness of products and services in tourism.

Stimulation of small and medium-size enterprises and creation of favorable conditions for attracting foreign investments are among the tasks of paramount importance for the state which should provide the initial conditions considering direct, indirect, induced effects of tourism and encourage capacity building. The establishment of a sustainable model of destination marketing and management should be a subject of broader discussions and partnerships aiming at longterm profitability through secure investments. A critical moment in that model would be the establishment of a destination brand equity and success ensuring safety and security in the sector substantiating sustainability embracing policies, governance, infrastructure, human capital, investments and marketing. Should this not be the case, the country risks a number of losses in revenues, employment rates, investments, image and much more when considering some more general human values.

\section{Conclusion}

Discussing international competitiveness of products and services in tourism in relation to the role of the sector for national economies and social development through the point of view of sustainable growth priorities, security aspects are an important factor along with a number of others linked to policy rules and regulations, health and hygiene, environmental protection, infrastructure, human, natural, cultural and other resources. Examining the sector development in Serbia, the study concludes on the importance of sharing responsibilities between state, private sector and community and assuring feedback on tourists' behavior and perceptions. Establishing a sustainable model of destination and marketing management is substantiated not only by the risks of economic losses but also by the necessity of a holistic approach towards tourism industry considering different aspects in their complexity and linkage to crisis management. The proposed actions should accent participatory and integrated approaches for achieving sustainable growth in the sector and contributing to country's sustainable development as a whole.

\section{REFERENCES}

Adeyinka-Ojo, S. F., Khoo-Lattimore, C., \& Nair, V. (2014). A framework for rural tourism destination management andmarketing organisations. Procedia - Social and Behavioral Sciences, 144, 151-163.

Albrechtsen, E. (2003). Security vs safety. NTNU - Norwegian University of Science and Technology. Department of Industrial Economics and Technology Management. Available at: http://www.iot.ntnu. no/users/albrecht/rapporter/notat\%20safety\%20v\%20security. pdf. Accessed: 12/2014.

Angelkova, T., Koteski, C., Jakovlev, Z., \& Mitrevska, E. (2012). Sustainability and competitiveness of tourism. Procedia - Social and Behavioral Sciences, 44, 221-227.

Anuar, A. N. A., Bookhari, S. N., \& Aziz, N. A. (2012). The Effectiveness of Safe City Programme as Safety Basic in Tourism Industry: Case Study in Putrajaya. Procedia - Social and Behavioral Sciences, 42, $477-485$.

Baldigara, T., \& Mamula, M. (2012). Tourism statistics in Croatia: Present status and future challenges. Procedia - Social and Behavioral Sciences, 44, 53-61.

Gabor, M. R., Codrina, L., \& Oltean F. D. (2012). A comparative analysis regarding European tourism competitiveness: emerging versus developed markets. Procedia Economics and Finance, 3, 361-366.

Jucan, C. N., \& Jucan, M. S. (2013). Travel and tourism as a driver of economic recovery. Procedia Economics and Finance, 6, 81-88. 
Wilks, J., \& Moore, S. (2004). Tourism Risk Manangement for the Asia Pacific Region: An Autorative Guide for the Managing of Crises and Disasters. Report prepared by the APEC International Centre for Sustainable Tourism.

Kamble, Z., \& Bouchon, F. (2014). Tourism planning and a nation's vision: A review of the tourismpolicy of Sri Lanka. Procedia-Social and Behavioral Sciences, 144, 229-236.

Kôvári, I., \& Zimányi K. (2011). Safety and security in the age of global tourism: the changing role and conception of Safety andSecurity in Tourism. Applied Studies in Agribusiness and Commerce Agroinform Publishing House, Budapest, 59-61.

Kingdom of Thailand. (2007). Disaster Prevention and Mitigation Act. B.E. 2550 [A.D. 2007]

Maximiliano, K. (2014). Foreword Two: Problems of Tourism Safety in Latin America. In Tourism Security. Strategies for Effectively Managing Travel Risk and Safety by Peter Tarlow. Available at: http://www.sciencedirect.com/science/book/9780124115705. Accessed: 12/2014.

Masfeld, Y, \& Pizam, A. (2005). Tourism, security and safety from theory to practice. Elsevier.

Petrović-Ranđelović, M., \& Miletić, D. (2012). (No) Competitiveness and Sustainable Development of Serbian Tourism. Procedia Social and Behavioral Sciences, 44, 78-87.

Prashyanusorn, V., Kaviya, S., \& Yupapin, P. P. (2010). Surveillance system for sustainable tourism with safety and privacy protection. Procedia Social and Behavioral Sciences, 2, 74-78.

Radović V. (2010). Concept of risk management from natural disasters in Serbian tourism industry. Poslovna ekonomija, 6 (4), 65-74.

Serbian Government. (2006). Strategy of tourism development in the Republic of Serbia. Available at http://www.srbija.gov.rs/vesti/ dokumenti_sekcija.php?id=45678. Retrieved on 3rd January 2015.

Serbia Travel \& Tourism Development Potential 2011-2023. World Travel and Tourism Council. Available at http://www.serbia. travel/download/WTTC_Serbia_Report.pdf. Accessed: 12/2014

Susmayadi, I. M., Sudibyakto, Kanagae, H., Adiyoso, W., \& Suryanti, E. D. (2014). Sustainable Disaster Risk Reduction through Effective Risk Communication Media in Parangtritis Tourism Area, Yogyakarta. Procedia Environmental Sciences 20, 684-692.

Travel \& Tourism Competitiveness Report 2013. Reducing Barriers to Economic Growth and Job Creation. Blanke, J., \& Chiesa, T., editors. World economic forum. Available at http://www.weforum.org/ reports/travel-tourism-competitiveness-report-2013. Accessed: $12 / 2014$

Yang, C. L., \& Nair, V. (2014). Risk perception study in tourism: Are we really measuring perceived risk? Procedia - Social and Behavioral Sciences, 144, 322-327.
The United Environmental Programme (UNEP) in cooperation with the Caribbean Alliance for Sustainable Tourism (CAST). (2008). Disaster Risk Management For Coastal Tourism Destinations Responding To Climate Change, A Practical Guide For Decision Makers, France. Available on: http://www.unep.fr/shared/ publications/pdf/DTIx1048xPA-DisasterRiskManagementforCoast alTourism.pdf. Retrieved on $10^{\text {th }}$ January 2015

Datum prijave rada: 21.04.2015

Datum prihvatanja rada: 21.09.2015.

\section{Kontakt}

Vesela Radović, Fakultet za primenjenu bezbednost, Sremska Kamenica, Vojvode Putnika 87

E-mail: veselaradovic@yahoo.com

Ekaterina Arabska, University of Agribusiness and Rural Development- UARD, 78, Dunav Blvd., Plovdiv Bulgaria

E-mail: katya_arabska@abv.bg 